\title{
ニホンウズラの血液型：同種免疫における 抗体産生能力の個体差および系統差
}

\author{
加藤秀樹 ·若杉 昇 \\ 名古屋大学農学部家畜育種学教室
}

Studies on the Blood Groups in the Japanese Quail :

Individual and $S t r a i n$ Diffèrences in Antibody Producing Ability in the Alloimmunization.

Hideki Katoh and Noboru Wakasugi

Laboratory of Animal Genetics, School of Agriculture, Nagoya University, Nagoya, 464

ニホンウズラ（Coturnix coturnix japonica)の実験動物としての重要性が指摘されてい るが (Wakasugi \& Kondo, 1973 : 河原, 1976 ), 免疫遺伝学の分野における使用例は少

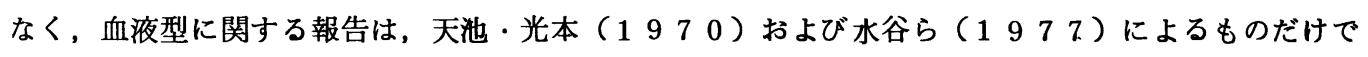
ある。我々は免疫遺伝学的研究に適したウズラ系統の育成を目的として血夜型の研究を行なってきて おり， $\mathrm{QN}_{1}$ 抗原， R抗原およびH抗原は，それぞれの常染色体性の優性遺伝子によって支配されて いることを明らかにした（Katoh \& Wakasugi，1980)。これに基づき当研究室において維 持されている 9 系統のウズラについて血夜型遺伝子の固定を行なってきており，ほぼ完成している。

血夜型の研究を行なう場合, 同じ特異性をもつ抗血清の補充が要求される。マウスおよびニワトリ では, 血夜型のわかっている系統がすでに有成されており, 目的とする抗血清の作製は，系統間免疫 によって容易に行なわれている（Klein, 1975 :Fujio \& Ezzeldin, 1974)。ウズラ のような小動物では十分な量の抗血清を得ることが困難なため, 上述のような抗血清作製システムの 早期確立が望まれる。

この報告では，血夜型のわかっている個体間および系統間での同種免疫の結果を述べる。

\section{材料および方法}

動物： 使用したウズラ系統およびそれらの血液型は, Table 1 に示されている。1 ストック 3 姉妹系統方式（各ストックは 3 つの姉妹系統より成り, 各系統はそれぞれローテーション交配によ って維持され, 時々ストック内の采統間交配を行ない生存力, 繁殖力の低下を防ぐ方式)により采統 維持が行なわれている。各系統の特徵および飼育方法は, Wakasugi \& Kondo（1973)によ り報告されている。

免疫方法：成䳝（５０日令以上）を使用し，同種免疫を 2 通りの方法により行なった。第 1 の方 法は, 天池・光本 $\left(\begin{array}{llll}1 & 9 & 7 & 0\end{array}\right)$ の方法である。つまり, donor の $2 \%$ 血球浮遊夜 $0.5 \mathrm{m \ell} 3$ 日毎に 


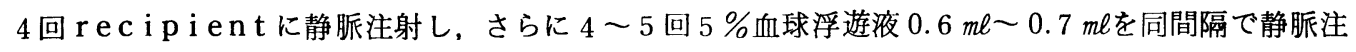
射した。第 2 の方法は, $10 \%$ 血球液遊液 $0.2 \mathrm{ml} 3$ 日毎に連続 5 回 r e c i p i e n t に静脈注射した。 採血は, 最終免疫後 $5 \sim 7$ 日にヘパリン入り注射筒を用いて行ない, $3000 \mathrm{r} \mathrm{pm} \mathrm{で} 10$ 分間遠心す ることにより抗血清を得た。

抗体価の測定および抗血清の特異性：Cooke 社製のマイクロプレートを使用し, 抗血清 $25 \mu 1$ を等量のP B Sで倍々希釈し, $2 \%$ 血球浮遊液を $25 \mu 1$ 加えて後, 凝集反応を観察した。抗体価測定 のための反応血球には donor 血球を用いた。得られた抗血清の特異性は, 血液型のわかっている赤 血球との反応により判定された。

Table 1, Three Stocks of the Japanese Quail Consisting of Nine Sister Strains and Their Blood Groups

\begin{tabular}{|c|c|c|c|c|}
\hline \multirow{2}{*}{ Stock No. } & \multirow{2}{*}{ St ra ins } & \multicolumn{3}{|c|}{ Blood groups } \\
\hline & & $\mathrm{QN}_{1}$ & $\mathrm{R}$ & $\mathrm{H}$ \\
\hline \multirow{3}{*}{1} & Sex-linked white (SW) & - & + & + \\
\hline & B r own (B) & - & + & + \\
\hline & Red-eyed brown (REB) & - & + & + \\
\hline \multirow{3}{*}{2} & Wild type plumage (WP) & - & - & - \\
\hline & Dominant Black (DB) & - & - & - \\
\hline & S i lver (S) & - & - & - \\
\hline \multirow{3}{*}{3} & Yell ow $(\mathrm{Y})$ & + & - & - \\
\hline & Black at hatch (BH) & + & - & - \\
\hline & Whit e (W) & + & - & - \\
\hline
\end{tabular}

結果

（1）抗体産生能力の個体差：天池 ·光本の方法を用い，血液型の異なるdonorにより 41 個体の r e c i p i ent を免疫した。そのうち 12 個体が既知のdonor抗原に対して抗体産生を行なった

(Table 2)。抗体価は 1：1〜1：128の範用であった。No.9390( $\left.\mathrm{QN}_{1}^{+}\right)$をdonorにして 4 個体の兄妹 (mongre 1) を免疫したが抗体産生は認められなかった。No.9460 ( donorにして 9 個体の兄妹（mong rel）を免疫した結果，5個体が抗体産生を行なった。また， No. 5851 およびNo.5853（SW系統一 $\mathrm{R}^{+}, \mathrm{H}^{+}$) をdonor にした場合 6 個体の親子（第 3 ストッ ク）すべてが抗体産生を行なった。しかしながら，同じ donor を用いて免疫したWP系統（第 2 ス トック)の 12 個体は, 抗体産生を行なわなかった。さらに, 抗体産生を示さなかった両親 (WP系 統）より得られた 6 個体の子供においても抗体産生が認められなかった。以上の結果より，抗体産生 能力に個体差があることが明らかにされ，抗体産生能の遺伝子支配が示唆された。 
Table 2. Titers and Specificities of Alloimmune Antisera

\begin{tabular}{|c|c|c|c|c|c|}
\hline \multicolumn{2}{|l|}{ Donor } & \multicolumn{2}{|c|}{ Recipient } & \multirow{2}{*}{ Titer } & \multirow{2}{*}{ Specificity } \\
\hline Wing No. & $\begin{array}{l}\text { Blood } \\
\text { groups }\end{array}$ & Wing No. & $\begin{array}{l}\text { Blood } \\
\text { groups }\end{array}$ & & \\
\hline \multirow[t]{6}{*}{9390} & \multirow{6}{*}{$\mathrm{QN}_{1}$} & $9 \overline{1} \overline{1}$ & $\mathrm{R}, \mathrm{H}$ & 0 & \\
\hline & & 9162 & $\mathrm{R}, \mathrm{H}$ & 0 & \\
\hline & & 9236 & $\mathrm{R}, \mathrm{H}$ & 0 & \\
\hline & & 9317 & $\mathrm{R}, \mathrm{H}$ & 0 & \\
\hline & & $\overline{9} \overline{3} \overline{2} \overline{3}$ & $\overline{\mathrm{R}}$ & 0 & \\
\hline & & 9324 & $\mathrm{R}$, $\mathrm{H}$ & $\times 8$ & Anti-?N $\mathrm{N}_{1}$ \\
\hline \multirow[t]{9}{*}{9460} & \multirow[t]{9}{*}{$\mathrm{R}, \mathrm{H}$} & $-\overline{9} \overline{4} \overline{1} \overline{0}^{--}$ & $\overline{\mathrm{Q}} \overline{\mathrm{N}}_{1} \overline{1}^{\prime}-\overline{\mathrm{R}}^{-}$ & $x 2$ & Anti-H \\
\hline & & 9412 & $\mathrm{QN}_{1}, \mathrm{R}$, & $x$ & Anti-H \\
\hline & & 9415 & - & 0 & \\
\hline & & 9440 & $\mathrm{QN}_{1}, \mathrm{H}$ & $\begin{array}{l}1 \\
1\end{array}$ & \\
\hline & & 9441 & $\mathrm{QN}_{1}, \mathrm{R}$ & $x 2$ & Anti-H \\
\hline & & 9443 & $\mathrm{QN}_{1}, \mathrm{H}$ & x128 & Anti-R \\
\hline & & 9452 & $\mathrm{H}$ & 0 & \\
\hline & & 9453 & $\mathrm{QN}_{1}$ & 0 & \\
\hline & & 9454 & $\mathrm{QN}_{1}, \mathrm{R}$ & $x 8$ & Anti-H \\
\hline 5851 & \multirow[t]{6}{*}{$R, H$} & $\lceil\overline{2} \overline{2} \overline{2} \overline{7}$ & $\bar{R}$ & x32 & Anti-R + H \\
\hline \multirow[t]{5}{*}{5853} & & 8447 & $\mathrm{QN}_{1}, \mathrm{R}$ & $\times 32$ & Anti-H \\
\hline & & $\overline{2} \overline{2} \overline{2}$ & & $x$ & Anti-H \\
\hline & & 2233 & $\mathrm{QN}_{1}, \mathrm{R}$ & $\times 8$ & Anti-H \\
\hline & & 2234 & $\mathrm{QN}_{1}, \mathrm{R}$ & $x 4$ & Anti-H \\
\hline & & 2235 & & $\begin{array}{ll}x & 4\end{array}$ & Anti-H \\
\hline
\end{tabular}

Individuals enclosed by the upper two broken rectangles are full-sibs. Wing No. 2227 and 8447 are the parents of the 2.232, 2233,2234 and 2235 .

（2）抗体産生能力の系統差：第2 の免疫方法を用いて, SW系統（第1ストック）をdonorにし, 第 2 ストック (WP，DBおよび S 系統) および第 3 ストック（Y，B HおよびW系統）を免疫した。 第 2 ストックを免疫した結果をTable 3 に示した。WP系統の 31 個体中 4 個体が抗体産生を行な 


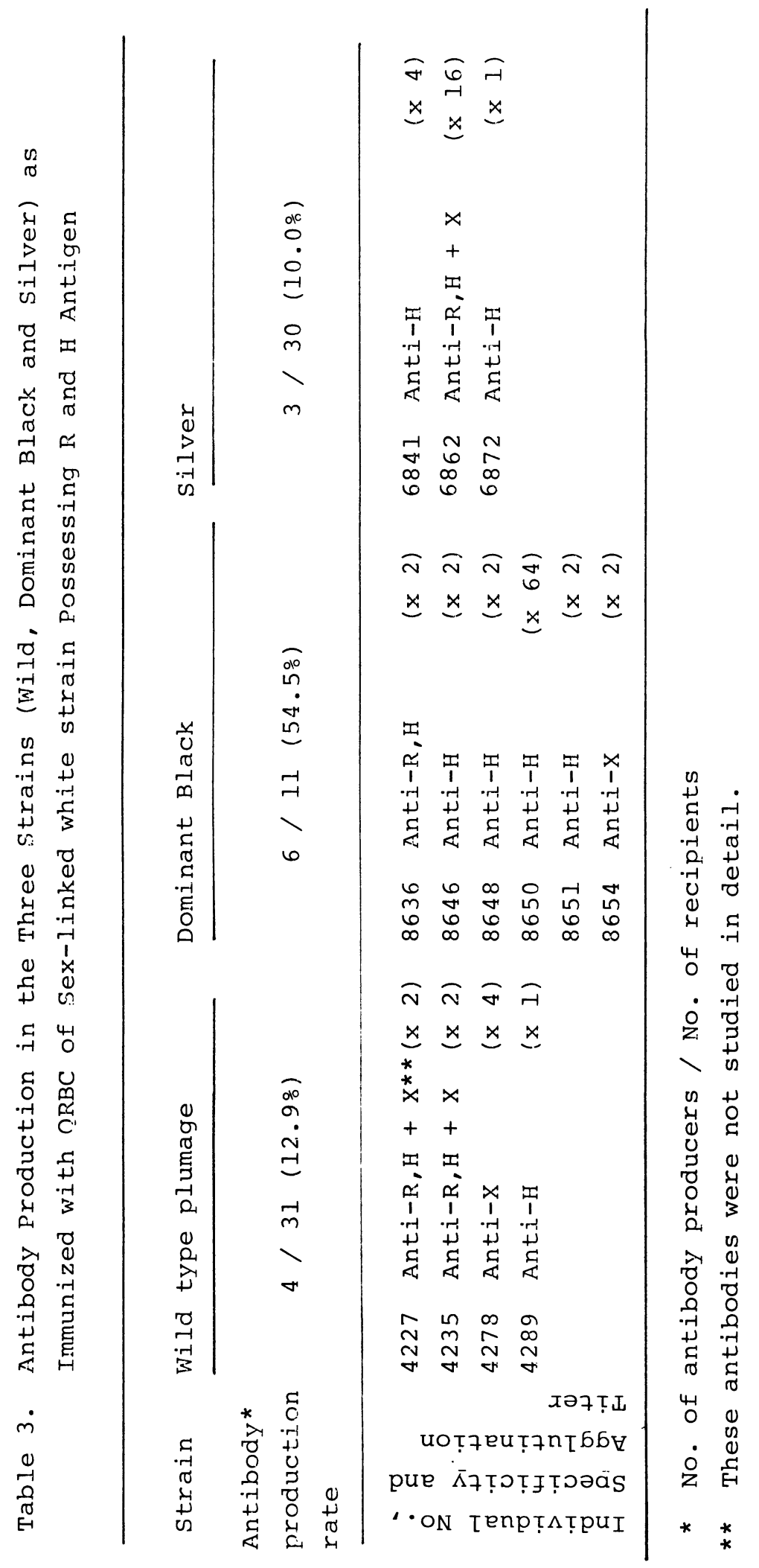




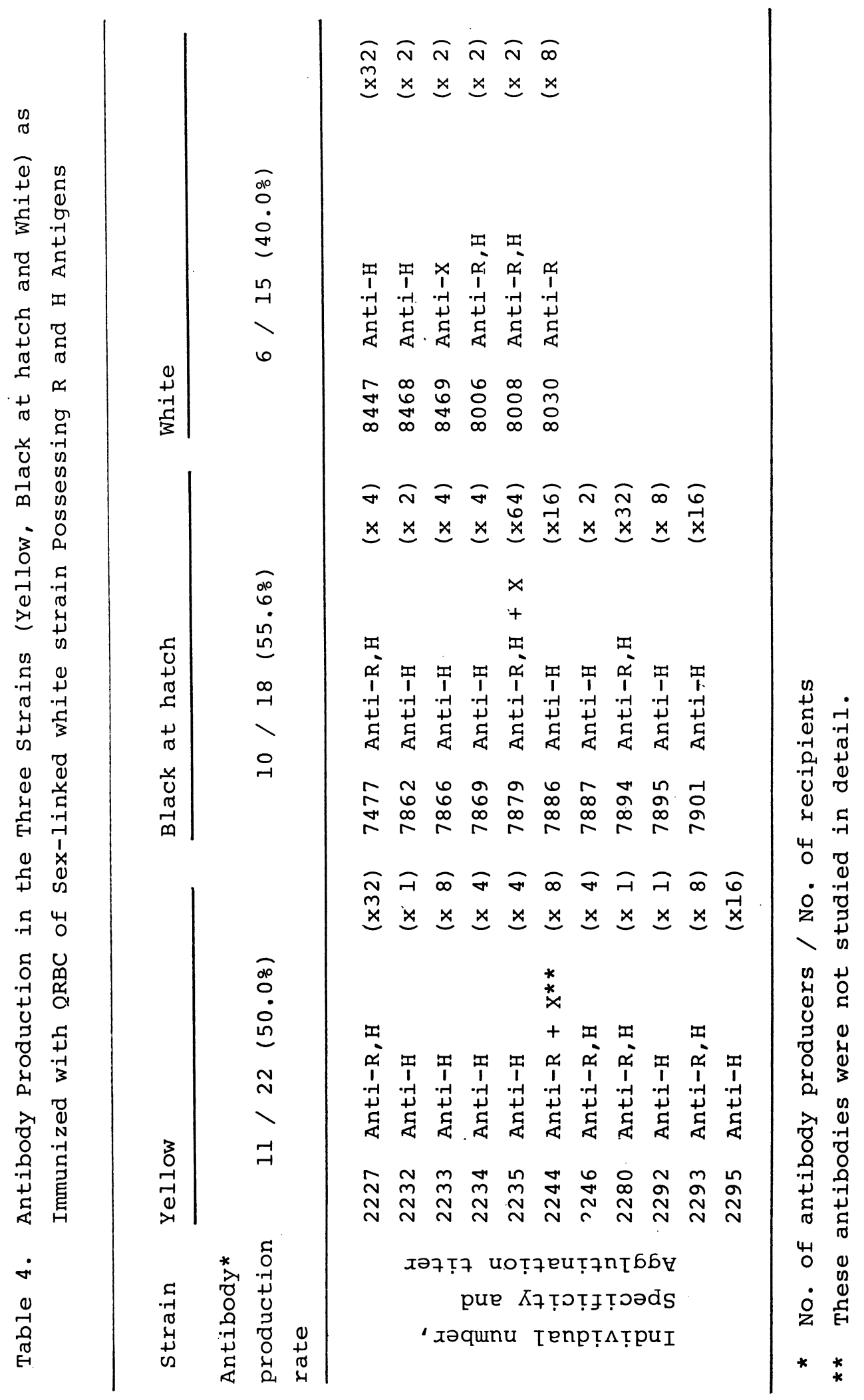


い, 抗体産生率は $12.9 \%$ であった。抗体価の範囲は, $1: 1 \sim 1: 4$ であった。S系統の 30 個体 中 3 個体に抗体産生が認められ，抗体産生率はWP系統とほぼ同じ $10 \%$ あった。抗体価は $1: 1$, $1 ： 4$ および $1 ： 16$ であった。それに対してD B系統は，1 1 個体中 6 個体が抗体産生を行ない。 WP，S両系統より明らかに高い抗体産生率（54.5\%) を示した。しかし抗体価は全体として低く, 5 個体が $1 ： 2$ で 1 個体が $1 ： 64$ であった。次に第 3 ストックを免疫した結果をTab le 4 に示し た。Y系統 22 個体中 11 個体が抗体産生を行ない，抗体産生率は $50 \%$ であった。抗体価の範囲は $1 ： 1 \sim 1 ： 32$ であったが, $1 ： 8$ 以下が 9 個体と多かった。B H系統では, 18 個体中 10 個体 が抗体産生を行ない，抗体産生率は $55.6 \%$ であった。抗体価の範囲は $1: 2 \sim 1: 64$ で, $1: 8$ 以下が 6 個体と多かったが，全体的にY系統よりも高い抗体価をもつ傾向が認められた。W系統にお いては，抗体産生が 15 個体中 6 個体に認められ，抗体産生率は $40 \%$ ，他の 2 系統より低い值を 示し，また, 抗体価も $1 ： 8$ 以下が 5 個体で全体的に B H系統より低い傾向がみられた。

以上の結果から，同種免疫における抗体産生能力に系統差が認められ，抗 $-\mathrm{R}$ およ゙抗 $-\mathrm{H}$ 抗体の

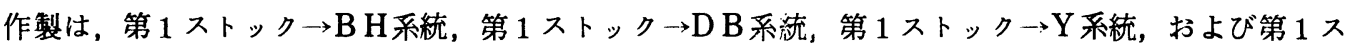
トック $\rightarrow \mathrm{W}$ 系統の組合せにおいてよい結果が得られた。

(3) 産生された特異的抗体の種類

抗体産生を行なった 40 個体中，抗一H抗体を産生した個体が 22 個体（55\%）ともっとも多く 抗一Hおよび抗－R抗体を同時に産生した個体は 13 個体 (32.5\%)であったが, 抗一 R抗体を産生 した個体は 2 個体 ( $5 \%$ ) だけであった。また，Hまたは R抗原以外の未知の抗原に対する抗体を産 生した個体が 3 個体 ( $7.5 \%$ ) あった（Table 3 および 4 )。系統によって特定の抗原に対して抗 体産生を行なうといった傾向はなかった。

考察

第 1 ストックの S w 系統を d o n o r にして, 第 2 および第 3 ストックの 6 系統に免疫した結果, 第 2 ストックでは D B 系統が他の 2 系統（WPおよび S 系統）上り高い抗体産生率を示した。この原因 は，次のように考えられる。つまり，WPおよびS 系統は系統としての育成期間が長いのに対して， D B 系統は 1976 年に豊橋の睬卵場より導入された羽装のミュータントであり育成期間が短かく, また系統育成において，W P および S 系統からの遺伝子の導入は行なったが，その逆は行なわなかっ た。従ってW Pおよび $\mathrm{S}$ 系統は，本来 $\mathrm{R}$ 抗原又は $\mathrm{H}$ 抗原に対する抗体産生能力が低いと考えられる。 それに対して，D B系統および第3 ストックの 3 系統（Y，B BおよびW系統）は，本来抗体産生能 力が高い系統であると考えられる。以上のことと, Table 2 に示した結果より, 同種免疫における 抗体産生能力は遺厷子の支配を受けていると考えられ, 抗体産生率の高低に基づく系統の選抜により

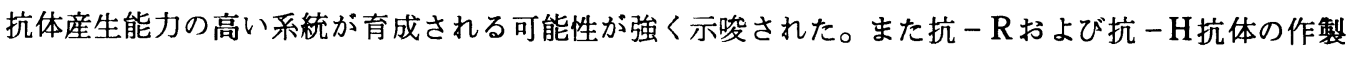
においてもっともよい組合せは，第 1 ストック $\rightarrow \mathrm{B} \mathrm{H}$ 系統であることが明らかにされた。本研究の目 的である能率の良い抗血清作製のための系統の組合せが見出されたことを意味する。

産生された抗体の抗体価は一般に低く，1：8 以下が全体の $75 \%$ を占めた。同種免疫における抗 体価は変動することが知られており, 免疫回数をさらに多くしても抗体価の上昇は期待できないと考 えられる。しかし，系統内の各個体は同じょうな免疫反応を示すため，異なる個体から得られた同じ 特異性の抗血清をプールすることによって, 多量の抗血清の作製が可能である。また，抗体産生能力 
の遺伝子支配が示唆されたので, 坑体価の高い系統の育成も可能と考えられ，今後の課題の 1 つであ る。

抗一H抗体だけを産生した個体が 40 個体中 22 個体あり，全体の $55 \%$ であったのに対して，抗一 $\mathrm{R}$ 抗体だけを産生した個体は 2 個体 $(5 \%)$ にすぎなかった。この結果は，H抗原と R 抗原の抗原性 の差を表わすものと考えられ, 前者の方が高いのかもしれない。Schierman \& McBride

( $\left.\begin{array}{llll}1 & 9 & 6 & 7\end{array}\right)$ は, ニワトリのB抗原が A システム抗原に対する抗体産生においてアジュバント効果を 示したことを報告した。ウズラにおいても同じ現象が認められるのかもしれないが，H抗原又はR抗 原だけを単独にもつdonor で免疫を行なわなかったので, 上記の現象との関係は明らかではない。 ニワトリでは同種免疫によって目的以外の抗原に対しても坑体産生が行なわれるために吸収操作が必 要である（Fujio \& Ezzeldin, 1974)。しかし, ウズラでは, Table 3および4に示し たように，吸収操作の必要がない場合が多く，ウズラの特改と考えられる。

この報告では，第 1 ストック $\left(\mathrm{QN}_{1}^{-}, \mathrm{R}^{+}, \mathrm{H}^{+}\right)$を第 2 ストック $\left(\mathrm{QN}_{1}^{-}, \mathrm{R}^{-}, \mathrm{H}^{-}\right)$および第 3 ストック $\left(\mathrm{QN}_{1}^{+}, \mathrm{R}^{-}, \mathrm{H}^{-}\right)$に免度して得られた結果を示したが，第 3 ストックから第 1 および第 2 ストックへの免疫を行なってみる必要があり, 今後の課題であろう。

要

䄪

血液型の異なる個体間での免疫および, 血液型の明らかな系統間での免疫により次の結果が得られ た。

（1）血縁関係の明らかな兄妹および親子を免度した結果, 抗体産生能力に個体差が認められ，その能 力は遺伝子の支配を受けていることが示唆された。

（2）抗体産生率を指標にして抗体産生能力を比較した場合, 明らかな系統差が認められ，B H系統,

D B系統， Y系統，W系統の順で高く，WP系統および $\mathrm{S}$ 系統は低かった。

（3）能率のよい抗血清作製のための系統の組合せを検討したところ，抗－ Rおよび抗－H血清は第 1 ストックをdonorにしてBH系統（第3ストック）を免疫した場合にもっとも効果的に作製される ことが明らかになった。

（4）抗体産生能力の遺伝子支配に関しさらに詳細な検討を行なうことおよび抗体産生能力（抗体産生 率）の高い采統の育成が今後の課題であろう。

謝辞

本研究にあたり, 適切な御指導を賜わった近藤恭司教授に, また, 動物飼育に関し御世話になった 早川つゆ技官に感謝する。

文献

天池孝子.光本孝次, 1970 帯畜大学研報, 6: 565-589.

Fujio, Y. and Z. A. Ezzeldin, 1974 Jap. J. Zootech. Sci., 45:412 -418 .

Kat oh, H. and N. Wakasugi, 1980 J. Develop. Comp. Immunol. (in press). 
Klein, J., 1975 Biology of the mouse histocompatibility-2 complex, pp. 81-127, Springer-Verlag New York Inc.

河原孝忠，1976 シンポジゥム 実験動物の開発改良（第 4 回） 一実験動物の純化と開発(1)講演集.

Mizutani, M., H. Ume zawa and S. Kuramasu, 1977 Jap. J. Zootech. Sci., $48: 227-234$.

Mizutani, M., H. Ume zawa and S. Kuramasu, 1977 Jap. J. Zootech. Sci., 48:463-467.

Schierman, L. W. and R. A. McBride, 1967 Science, 156:658-659. Wakasugi, N. and K. Kondo, 1973 Exp. Anim, 22:151-159. 